\title{
Independent factors associated with serum levels of 25- Hydroxyvitamin D in very elderly Chinese males
}

\author{
Pingda Bian ${ }^{1}$, Xue Jin ${ }^{2}$, Zhangxuan Shou ${ }^{2 *}$, Jue Wang ${ }^{1}$ and Xiuyang $\mathrm{Li}^{3}$ \\ ${ }^{1}$ Center for Diagnosis and Treatment of Osteoporosis, Zhejiang Provincial People's Hospital, People's Hospital of Hangzhou Medical College, Hangzhou, China \\ ${ }^{2}$ Department of Pharmaceutical Sciences, Zhejiang Provincial People's Hospital, People's Hospital of Hangzhou Medical College, Hangzhou, China \\ ${ }^{3}$ Department of Epidemiology and Health Statistics, Zhejiang University, Hangzhou, China
}

\begin{abstract}
Background: Vitamin D deficiency has been associated with a wide variety of chronic diseases and even all-cause mortality. Data on serum 25 -hydroxyvitamin D $[25(\mathrm{OH}) \mathrm{D}]$ and its independent factors in very elderly (aged 80 years or more) males remain to be fully explored. This study was designed to identify independent factors associated with the serum levels of $25(\mathrm{OH}) \mathrm{D}$ in very elderly Chinese males.

Materials and methods: A total of 903 very elderly Chinese males were recruited in the study, and subjected to surveys on underlying chronic diseases and lifestyle factors. The serum levels of 25(OH)D, bone turnover markers (BTMs), parathyroid hormone (PTH), sex steroid hormones, and biochemical parameters were assayed. Univariate and multivariate regression analyses were performed to identify independent factors associated with the serum levels of $25(\mathrm{OH}) \mathrm{D}$.

Results: There were $245(27.1 \%)$ subjects with insufficient vitamin D, and $499(55.3 \%)$ subjects with deficient vitamin D. It was demonstrated that sun exposure $(\beta=0.974, P=0.042)$, serum apolipoprotein $\mathrm{A} 1(\beta=2.889, \mathrm{P}=0.026)$ and calcium $(\beta=17.429, \mathrm{P}<0.0001)$ were positively associated with the serum concentrations of $25(\mathrm{OH}) \mathrm{D}$, while alcohol drinking $(\beta=-3.126, \mathrm{P}=0.031)$, serum $\mathrm{PTH}(\beta=-0.072, \mathrm{P}=0.002)$ and triglycerides $(\beta=-1.868, \mathrm{P}=0.009)$ were negatively associated with the serum concentrations of $25(\mathrm{OH}) \mathrm{D}$ in 903 very elderly Chinese males.
\end{abstract}

Conclusions: There is a high prevalence of vitamin D insufficiency and deficiency in very elderly Chinese males. Some lifestyle factors are associated with the serum concentrations of $25(\mathrm{OH}) \mathrm{D}$.

\section{Background}

Vitamin D deficiency has become an ever-increasing health challenge around the globe. An investigation suggested that according to certain "reference ranges", about one billion people across all ethnicities and age groups in the world have vitamin D insufficiency or deficiency [1]. In European women aged over 80 years, the prevalence of 25 -hydroxyvitamin D [25(OH)D] inadequacy was $80.9 \%$ and $44.5 \%$ [2] when considering cut-offs of $30 \mathrm{ng} / \mathrm{ml}$ and $20 \mathrm{ng} / \mathrm{ml}$, respectively. Despite significant daily sunlight availability in Africa and the Middle East, persons living in these regions are frequently vitamin D insufficient or deficient. The percentages of Vitamin D insufficiency $(25(\mathrm{OH}) \mathrm{D}$ between 15 and $20 \mathrm{ng} / \mathrm{ml}$ ) were described from $5 \%$ to $80 \%$ in various population groups in these areas [3]. In addition, the prevalence of vitamin D deficiency $(25(\mathrm{OH}) \mathrm{D}$ levels less than $20 \mathrm{ng} / \mathrm{mL})$ in a Chinese population aged 40-75years was reported to be $75.2 \%$ [4].

Vitamin D deficiency gains more and more attention because it not only leads to osteopenia, osteoporosis [5] and increased fall [6] and fracture risk [7], but also mounting evidence has implied its role as an emerging risk factor for a good variety of chronic diseases [8]. A series of observational studies reported that low circulating concentrations of $25(\mathrm{OH}) \mathrm{D}$ were associated with high risk for cardiovascular diseases [9], cerebrovascular disease [10], cancer [11], type 2 diabetes mellitus [12], cognitive impairment [13], depression [14], orthostatic hypotension [15], and even all-cause mortality [16].

Vitamin D is found in very few foods such as egg yolk, pelagic fish and rare plants or mushrooms, and endogenous production through exposure of the skin to ultraviolet B light is the major source of Vitamin $\mathrm{D}$ [17]. Vitamin D obtained from sun exposure, foods and supplements is biologically inactive and must undergo hydroxylation in the body for activation. Serum concentration of $25(\mathrm{OH}) \mathrm{D}$ is the best indicator of vitamin D status [18]. It reflects vitamin D produced cutaneously and that obtained from food and supplements, and has a fairly long circulating half-life of 15 days [19]. Despite the fact that many studies have reported factors associated with serum $25(\mathrm{OH}) \mathrm{D}$ concentrations such as age, body mass index, ethnicity, skin pigmentation, latitude, altitude and season [20], to our knowledge, data on serum 25-hydroxyvitamin D [25(OH)D] and its independent factors in very elderly (aged 80 years or more) males remain to be fully explored [21].

With an attempt to identify factors independently associated with the serum levels of $25(\mathrm{OH}) \mathrm{D}$ in very elderly males, we conducted an investigation of lifestyle factors and underlying chronic diseases,

Correspondence to: Dr. Zhangxuan Shou, Department of Pharmaceutical Sciences, Zhejiang Provincial People's Hospital, People's Hospital of Hangzhou Medical College, No. 158 Shangtang Road, Hangzhou 310014, China. Tel: +8613588173827, Email: shousor@126.com

Key words: 25-hydroxyvitamin D, sun exposure, parathyroid hormone, apolipoprotein A-I, very elderly

Received: December 28, 2016; Accepted: January 24, 2017; Published: January 28,2017 
and detected the serum levels of bone turnover markers (BTMS), biochemical parameters and sex steroid hormones in 903 very elderly Chinese males.

\section{Materials and methods}

\section{Study subjects}

A total of 903 Chinese Han males who underwent a physical examination in Zhejiang Provincial People's Hospital from January 2013 through December 2014 were enrolled in the study. The inclusion criteria were: 1) Chinese Han males aged 80 years or more; 2) Being capable of receiving questionnaire survey and undertaking BTMs, biochemical parameters and sex steroid hormones measurements. The exclusion criteria were: 1) With one of the clinical conditions including dementia, severe hepatic dysfunction, severe renal dysfunction and advanced malignancy; 2) On vitamin D and active vitamin D supplementary treatment, including 1 a-hydroxyvitamin D3 and 1, 25-hydroxyvitamin D3.

Written informed consent were obtained from all participants, and the study got approval from the institutional review board of Zhejiang Provincial People's Hospital.

\section{Anthropometric measure}

For all participants, age was recorded, weight $(\mathrm{kg})$ and height $(\mathrm{m})$ were measured barefoot and in lightweight indoor clothing, and the body mass index (BMI, $\mathrm{kg} / \mathrm{m}^{2}$ ) was obtained as the result of weight divided by squared height.

\section{Surveys of lifestyle factors and underlying chronic diseases}

Data on underlying chronic diseases including hypertension, coronary heart disease, type 2 diabetes mellitus, chronic obstructive pulmonary disease (COPD) and chronic gastritis were collected based on medical history and verified in accordance with guidelines for specific diseases.

A self-designed questionnaire was used for obtaining the information on lifestyle factors of participants, including cigarette smoking, alcohol drinking, sun exposure, physical activity, intake of milk or dairy products. This questionnaire was designed on the basis of the characteristics of very elderly males, risk factors for osteoporosis [22], and referring to the WHO Fracture Risk Assessment Tool (FRAX) [23]. The detailed questionnaire is as follows (Table 1).

\section{Assays of serum 25(OH)D, BTMs and parathyroid hormone}

After fasting overnight, venous blood samples were collected from all participants between 7:00 and 9:00 AM. The blood samples were centrifuged and stored at $-80^{\circ} \mathrm{C}$ for further analysis. Serum levels of $25(\mathrm{OH}) \mathrm{D}$, parathyroid hormone $(\mathrm{PTH})$ and BTMs were measured with electrochemiluminescence immunoassay using an automatic device (Roche cobas e 601 Automated Analyzer, Roche Diagnostics, Tokyo, Japan). The intra- and inter-assay coefficient of variation (CV) were $1.4 \%$ and $3.5 \%$ for $25(\mathrm{OH}) \mathrm{D}, 2.0 \%$ and $4.2 \%$ for $\beta$-C-telopeptide of type 1 collagen ( $\beta$-CTX), $0.8 \%$ and $4.0 \%$ for $\mathrm{N}$-terminal propeptide of type 1 collagen (P1NP), $0.5 \%$ and $1.4 \%$ for osteocalcin, and $1.1 \%$ and $2.0 \%$ for PTH, respectively. In accordance with the international standard for vitamin D status [24], a serum levels of $25(\mathrm{OH}) \mathrm{D}<20$ $\mathrm{ng} / \mathrm{ml}(50 \mathrm{nmol} / \mathrm{L})$ was defined as deficiency, $20 \mathrm{ng} / \mathrm{ml}(50 \mathrm{nmol} / \mathrm{L}) \leq$ $25(\mathrm{OH}) \mathrm{D}<30 \mathrm{ng} / \mathrm{ml}(75 \mathrm{nmol} / \mathrm{L})$ as insufficiency, and $25(\mathrm{OH}) \mathrm{D} \geq 30$ $\mathrm{ng} / \mathrm{ml}(75 \mathrm{nmol} / \mathrm{L})$ as normal.

\section{Detections of sex steroid hormones}

Sex steroid hormones were detected with electrochemiluminescence immunoassay using an automatic device (ARCHITECT Plus i2000SR, Abbott Diagnostics, IL, USA). The intra- and inter-assay CV were $4.9 \%$ and $7.7 \%$ for follicle-stimulating hormone, $5.7 \%$ and $7.0 \%$ for luteinizing hormone, $4.3 \%$ and $5.9 \%$ for estradiol, $3.9 \%$ and $6.3 \%$ for prolactin, $5.2 \%$ and $8.1 \%$ for progesterone, and $3.5 \%$ and $6.2 \%$ for testosterone, respectively.

\section{Determinations of biochemical parameters}

Biochemical parameters were determined by using an automatic biochemistry analyzer (HITACHI 7600-010 Automatic Analyzer, Hitachi High-Technologies, Tokyo, Japan) with standard methods. The intra- and inter-assay CV were $2.4 \%$ and $4.2 \%$ for uric acid, $2.0 \%$ and $3.1 \%$ for glucose, $2.5 \%$ and $4.0 \%$ for creatinine, $3.5 \%$ and $5.2 \%$ for triglyceride, $2.0 \%$ and $3.7 \%$ for total cholesterol, $3.8 \%$ and $5.3 \%$ for high-density lipoprotein cholesterol (HDL-C), $3.8 \%$ and $6.4 \%$ for low-density lipoprotein cholesterol (LDL-C), 2.3\% and 5.3\% for apolipoprotein $\mathrm{A} 1,3.6 \%$ and $6.1 \%$ for apolipoprotein $\mathrm{B}, 2.0 \%$ and $4.7 \%$ for high sensitivity C-reactive protein (Hs-CRP), $1.5 \%$ and $2.9 \%$ for potassium, $1.2 \%$ and $3.3 \%$ for sodium, $2.0 \%$ and $5.5 \%$ for calcium, $2.7 \%$ and $4.2 \%$ for phosphate, $4.0 \%$ and $6.5 \%$ for iron, and $4.3 \%$ and $7.0 \%$ for alkaline phosphatase, respectively.

\section{Statistical analysis}

All statistical analyses were performed by using SPSS 17.0 for Windows (SPSS Inc., IBM Company, Chicago, USA). Continuous data were expressed as mean \pm standard deviation (SD), and nominal data were expressed as numbers and percentages. The one-sample Kolmogorov-Smirnov test was conducted to assess data distribution, and the independent-samples $t$ test was performed for group comparisons. The linear correlation was estimated by using Pearson's simple correlation coefficient. Variables significant in univariate analysis were included in the multivariate analysis. A multivariate linear regression was conducted to find independent factors associated

Table 1. Questionnaire on lifestyle factors of very elderly males.

\begin{tabular}{|c|c|c|c|}
\hline No. & Questions & Responses & Definitions \\
\hline 1 & Do you smoke every day, or some days per week? & $\begin{array}{l}\text { Yes } \\
\text { No }\end{array}$ & $\begin{array}{l}\text { Current smoker } \\
\text { Not current smoker }\end{array}$ \\
\hline 2 & $\begin{array}{l}\text { Do you drink three units (one unit equivalent to } 285 \mathrm{ml} \text { beer, } 30 \mathrm{ml} \text { liquor or } \\
120 \mathrm{ml} \text { wine) of alcoholic beverage every day, or more? }\end{array}$ & $\begin{array}{l}\text { Yes } \\
\text { No }\end{array}$ & $\begin{array}{l}\text { Drinker } \\
\text { Not drinker }\end{array}$ \\
\hline 3 & $\begin{array}{l}\text { Do you expose to sunshine for } 15-30 \text { minutes between } 10 \mathrm{AM} \text { and } 3 \mathrm{PM} \text { twice } \\
\text { a week to the face, arms, legs, or back without sunscreen, or more? }\end{array}$ & $\begin{array}{l}\text { Yes } \\
\text { No }\end{array}$ & $\begin{array}{l}\text { Having adequate sun exposure } \\
\text { Not having adequate sun exposure }\end{array}$ \\
\hline 4 & Do you take exercise for 30 minutes every day, four days per week, or more? & $\begin{array}{l}\text { Yes } \\
\text { No }\end{array}$ & $\begin{array}{l}\text { Taking regular exercise } \\
\text { Not taking regular exercise }\end{array}$ \\
\hline 5 & $\begin{array}{l}\text { Do you have } 200 \mathrm{ml} \text { milk or equivalent dairy products every day, four days per } \\
\text { week, or more? }\end{array}$ & $\begin{array}{l}\text { Yes } \\
\text { No }\end{array}$ & $\begin{array}{l}\text { Having enough milk or dairy products } \\
\text { Not having enough milk or dairy products }\end{array}$ \\
\hline
\end{tabular}


with serum $25(\mathrm{OH}) \mathrm{D}$. All statistical tests were two-sided, and $P$ values $<0.05$ were considered statistically significant.

\section{Results}

\section{Demographic characteristics of the participants}

The study included 903 Chinese males, with a mean age of 83.93 \pm 3.55 years (range from 80 to 97 ). According to the serum levels of $25(\mathrm{OH}) \mathrm{D}$, there were $159(17.6 \%)$ subjects with normal vitamin D, 245 (27.1\%) subjects with insufficient vitamin D, and 499 (55.3\%) subjects with deficient vitamin D.

The relationship between serum $25(\mathrm{OH}) \mathrm{D}$ and chronic diseases and lifestyle factors in 903 very elderly Chinese males

The association between serum 25(OH)D and underlying chronic diseases and lifestyle factors were analyzed in all participants. It was found that the subjects with hypertension had a mean serum $25(\mathrm{OH})$ D levels of $17.45 \pm 8.46 \mathrm{ng} / \mathrm{ml}$, significantly lower than those without hypertension $(19.82 \pm 8.10 \mathrm{ng} / \mathrm{ml}, t=-2.208, P=0.028)$, the drinkers had a mean serum $25(\mathrm{OH}) \mathrm{D}$ levels of $14.42 \pm 6.93 \mathrm{ng} / \mathrm{ml}$, significantly lower than non-drinkers $(18.47 \pm 8.47 \mathrm{ng} / \mathrm{ml}, t=-2.404, P=0.017)$, and the mean serum levels of $25(\mathrm{OH}) \mathrm{D}$ in subjects who had adequate sun exposure was $18.76 \pm 8.26 \mathrm{ng} / \mathrm{ml}$, significantly higher than that in subjects who hadn't $(16.18 \pm 8.61 \mathrm{ng} / \mathrm{ml}, t=1.925, P=0.042)$. Other lifestyle factors and underlying chronic diseases were not correlated to the serum levels of $25(\mathrm{OH}) \mathrm{D}$ in 903 very elderly Chinese males, as shown in table 2.

Table 2. Relationship between serum $25(\mathrm{OH}) \mathrm{D}$ and chronic diseases and lifestyle factors in 903 very elderly Chinesemales.

\begin{tabular}{|c|c|c|c|c|}
\hline Parameters & Number (\%) & 25(OH)D (ng/ml) & $t$ & $\boldsymbol{P}$ \\
\hline Hypertension & & & -2.208 & 0.028 \\
\hline Yes & $651(72.1)$ & $17.45 \pm 8.46$ & & \\
\hline No & $252(27.9)$ & $19.82 \pm 8.10$ & & \\
\hline Coronary heart disease & & & 1.633 & 0.104 \\
\hline Yes & $105(11.6)$ & $20.29 \pm 9.34$ & & \\
\hline No & $798(88.4)$ & $17.82 \pm 8.26$ & & \\
\hline Type 2 diabetes mellitus & & & -0.822 & 0.412 \\
\hline Yes & 207 (22.9) & $17.42 \pm 8.78$ & & \\
\hline No & $696(77.1)$ & $18.37 \pm 8.28$ & & \\
\hline COPD & & & -0.247 & 0.805 \\
\hline Yes & $183(20.3)$ & $17.87 \pm 7.37$ & & \\
\hline No & $720(79.7)$ & $18.17 \pm 8.67$ & & \\
\hline Chronic gastritis & & & -0.769 & 0.443 \\
\hline Yes & $246(27.2)$ & $17.38 \pm 7.23$ & & \\
\hline No & $657(72.8)$ & $18.30 \pm 8.70$ & & \\
\hline Current smoker & & & -1.534 & 0.126 \\
\hline Yes & $48(5.3)$ & $16.98 \pm 7.51$ & & \\
\hline No & $855(94.7)$ & $18.28 \pm 8.44$ & & \\
\hline Drinker & & & -2.404 & 0.017 \\
\hline Yes & $81(9.0)$ & $14.42 \pm 6.93$ & & \\
\hline No & $822(91.0)$ & $18.47 \pm 8.47$ & & \\
\hline Having adequate sun exposure & & & 1.925 & 0.042 \\
\hline Yes & $606(67.1)$ & $18.76 \pm 8.26$ & & \\
\hline No & $297(32.9)$ & $16.18 \pm 8.61$ & & \\
\hline Taking regular exercise & & & 0.981 & 0.327 \\
\hline Yes & $783(86.7)$ & $18.29 \pm 8.36$ & & \\
\hline No & $120(13.3)$ & $16.89 \pm 9.34$ & & \\
\hline Having enough milk or dairy products & & & 1.199 & 0.231 \\
\hline Yes & $712(78.8)$ & $18.50 \pm 8.61$ & & \\
\hline No & $191(21.2)$ & $17.25 \pm 7.95$ & & \\
\hline
\end{tabular}

Abbreviation: $\boldsymbol{C O P D}$ chronic obstructive pulmonary disease
The correlation of serum 25(OH)D with BTMs, PTH, biochemical parameters and sex steroid hormones in 903 very elderly Chinese males

The correlation between serum $25(\mathrm{OH}) \mathrm{D}$ levels and quantitative parameters including age, BMI, BTMs, $\mathrm{PTH}$, biochemical parameters and sex steroid hormones were also evaluated in all participants. It was demonstrated that serum $25(\mathrm{OH}) \mathrm{D}$ was significantly associated with $\beta$-CTX, P1NP, PTH, triglycerides, apolipoprotein A1 and calcium, while other parameters such as osteocalcin, uric acid and sex steroid hormones were not related to serum $25(\mathrm{OH}) \mathrm{D}$, as shown in Table 3 .

\section{Multivariate analysis of 25( $\mathrm{OH}) \mathrm{D}$ with clinical parameters in 903 very elderly Chinese males}

A multivariate regression analysis was carried out with serum $25(\mathrm{OH}) \mathrm{D}$ being used as the dependent variable, while the status of hypertension, alcohol drinking, sun exposure, serum levels of $\mathrm{PTH}, \beta$-CTX, P1NP, triglycerides, apolipoprotein A1 and calcium as independent variables. The results revealed that sun exposure $(\beta=0.974, P=0.042)$, serum apolipoprotein $\mathrm{A} 1(\beta=2.889, P=0.026)$ and calcium $(\beta=17.429, P<0.0001)$ were positively associated with the serum levels of $25(\mathrm{OH}) \mathrm{D}$, while alcohol drinking $(\beta=-3.126, P=0.031)$, serum PTH $(\beta=-0.072, P=0.002)$ and triglycerides $(\beta=-1.868, P=0.009)$ were negatively associated with the serum concentrations of $25(\mathrm{OH}) \mathrm{D}$ in 903 very elderly Chinese males, as shown in Table 4.

Table 3. Correlation of serum 25(OH)D with BTMs, biochemical parameters and sex steroid hormones in 903 very elderly Chinesemales.

\begin{tabular}{|l|l|l|l|}
\hline \multicolumn{1}{|c|}{ Variables } & $\bar{x} \pm s$ & $\boldsymbol{r}_{s}$ & $\boldsymbol{P}$ \\
\hline Age $(\mathrm{year})$ & $83.93 \pm 3.55$ & -0.001 & 0.989 \\
\hline BMI $\left(\mathrm{kg} / \mathrm{m}^{2}\right)$ & $24.17 \pm 3.13$ & -0.079 & 0.169 \\
\hline$\beta$-CTX $(\mathrm{ng} / \mathrm{ml})$ & $0.35 \pm 0.20$ & -0.126 & 0.028 \\
\hline P1NP $(\mathrm{ng} / \mathrm{ml})$ & $39.02 \pm 18.56$ & -0.119 & 0.040 \\
\hline Osteocalcin $(\mathrm{ng} / \mathrm{ml})$ & $16.70 \pm 7.58$ & -0.110 & 0.057 \\
\hline PTH $(\mathrm{pg} / \mathrm{ml})$ & $50.00 \pm 21.35$ & -0.215 & $<0.0001$ \\
\hline Uric acid $(\mu \mathrm{mol} / \mathrm{L})$ & $375.32 \pm 88.32$ & 0.043 & 0.456 \\
\hline Glucose $(\mathrm{mmol} / \mathrm{L})$ & $5.82 \pm 1.34$ & 0.009 & 0.876 \\
\hline Creatinine $(\mu \mathrm{mol} / \mathrm{L})$ & $105.27 \pm 29.90$ & -0.069 & 0.235 \\
\hline Triglycerides $(\mathrm{mmol} / \mathrm{L})$ & $1.32 \pm 0.67$ & -0.120 & 0.038 \\
\hline Total cholesterol $(\mathrm{mmol} / \mathrm{L})$ & $4.68 \pm 1.02$ & 0.016 & 0.779 \\
\hline HDL-C $(\mathrm{mmol} / \mathrm{L})$ & $1.32 \pm 0.34$ & 0.093 & 0.108 \\
\hline LDL-C $(\mathrm{mmol} / \mathrm{L})$ & $2.79 \pm 0.95$ & 0.045 & 0.438 \\
\hline Apolipoprotein A1 $(\mathrm{g} / \mathrm{L})$ & $1.50 \pm 0.37$ & 0.123 & 0.033 \\
\hline Apolipoprotein B $(\mathrm{g} / \mathrm{L})$ & $0.86 \pm 0.25$ & -0.027 & 0.639 \\
\hline Hs-CRP $(\mathrm{mg} / \mathrm{L})$ & $4.35 \pm 3.17$ & 0.091 & 0.118 \\
\hline Potassium $(\mathrm{mmol} / \mathrm{L})$ & $4.06 \pm 0.36$ & -0.067 & 0.248 \\
\hline Sodium $(\mathrm{mmol} / \mathrm{L})$ & $140.61 \pm 2.65$ & 0.092 & 0.112 \\
\hline Calcium $(\mathrm{mmol} / \mathrm{L})$ & $2.33 \pm 0.11$ & 0.181 & 0.002 \\
\hline Phosphate $(\mathrm{mmol} / \mathrm{L})$ & $1.06 \pm 0.16$ & -0.032 & 0.582 \\
\hline Iron $(\mu \mathrm{mol} / \mathrm{L})$ & $17.92 \pm 5.85$ & -0.080 & 0.170 \\
\hline Alkaline $\mathrm{phosphatase}(\mathrm{U} / \mathrm{L})$ & $76.71 \pm 22.35$ & -0.047 & 0.415 \\
\hline Follicle-stimulating hormone $(\mathrm{IU} / \mathrm{L})$ & $23.83 \pm 18.18$ & -0.017 & 0.793 \\
\hline Luteinizing hormone $(\mathrm{IU} / \mathrm{L})$ & $10.87 \pm 7.41$ & -0.059 & 0.346 \\
\hline Estradiol $(\mathrm{pg} / \mathrm{ml})$ & $26.64 \pm 11.01$ & -0.047 & 0.465 \\
\hline Prolactin $(\mathrm{ng} / \mathrm{ml})$ & $19.45 \pm 13.18$ & -0.055 & 0.385 \\
\hline Progesterone $(\mathrm{ng} / \mathrm{ml})$ & $0.31 \pm 0.19$ & 0.021 & 0.756 \\
\hline Testosterone $(\mathrm{ng} / \mathrm{ml})$ & $4.61 \pm 2.54$ & 0.031 & 0.618 \\
\hline & & \\
\hline
\end{tabular}

Abbreviation: $\boldsymbol{B M I}$ body mass index, $\boldsymbol{P T H}$ parathyroid hormone, $\boldsymbol{\beta}$ - $\boldsymbol{C T X} \boldsymbol{\beta}$-C-telopeptide of type 1 collagen, PINP N-terminal propeptide of type 1 collagen, $\boldsymbol{H D L}-\boldsymbol{C}$ high-density lipoprotein cholesterol, $\boldsymbol{L D L}$ - $\boldsymbol{C}$ low-density lipoprotein cholesterol, $\boldsymbol{H} \boldsymbol{s}-\boldsymbol{C R} \boldsymbol{P}$ high sensitivity C-reactive protein 
Table 4. Multivariate analysis of clinical parameters associated with $25(\mathrm{OH}) \mathrm{D}$ in 903 elderly Chinese males.

\begin{tabular}{|c|c|c|c|c|c|}
\hline \multirow[t]{2}{*}{ Variables } & \multirow[t]{2}{*}{$\beta$} & \multicolumn{2}{|c|}{$95 \% C I$} & \multirow[t]{2}{*}{$t$} & \multirow[t]{2}{*}{$P$} \\
\hline & & lower & upper & & \\
\hline Hypertension & -1.684 & -3.679 & 0.311 & -1.661 & 0.098 \\
\hline Alcohol drinking & -3.126 & -6.266 & -0.013 & -2.051 & 0.031 \\
\hline Sun exposure & 0.974 & -0.930 & 2.878 & 1.892 & 0.042 \\
\hline$\beta$-CTX & -0.003 & -0.010 & 0.003 & -1.106 & 0.270 \\
\hline P1NP & 0.000 & -0.067 & 0.066 & -0.010 & 0.992 \\
\hline PTH & -0.072 & -0.117 & -0.027 & -3.162 & 0.002 \\
\hline Triglycerides & -1.868 & -3.264 & -0.472 & -2.633 & 0.009 \\
\hline Apolipoprotein A1 & 2.889 & 0.347 & 5.452 & 2.236 & 0.026 \\
\hline Calcium & 17.429 & 8.300 & 26.558 & 3.718 & $<0.0001$ \\
\hline
\end{tabular}

Abbreviation: $\boldsymbol{C I}$ confidence interval, $\boldsymbol{P T H}$ parathyroid hormone, $\boldsymbol{\beta}$ - $\boldsymbol{C T X} \boldsymbol{\beta}$-C-telopeptide of type 1 collagen, $\boldsymbol{P} 1 \boldsymbol{N} \boldsymbol{P}$ N-terminal propeptide of type 1 collagen

\section{Discussion}

Vitamin D deficiency is extremely common among elderly persons, which is caused by insufficient sunlight exposure, decreased function of the skin to synthesize vitamin D, low dietary intake of vitamin D and etc [25]. Similar to other findings [26,27], we found the prevalence of vitamin D deficiency and insufficiency was as high as $82.4 \%$ in 903 very elderly Chinese Males.

Vitamin D promotes calcium absorption in the gut and maintains adequate serum calcium and phosphate concentrations. In the case of vitamin $\mathrm{D}$ deficiency, the active absorption of calcium from intestine decreases. The resulting low serum calcium stimulates the release of PTH through an action on the calcium-sensing receptors located on parathyroid cells. Increased PTH levels in turn induce the enzyme activity of $1 a$-hydroxylase in the kidney, which converts $25(\mathrm{OH}) \mathrm{D}$ to its active form, calcitriol. Therefore, an inverse association between serum 25(OH)D and PTH has been well established [28]. In accordance with the results by Olmos and coworkers [29], we found that serum PTH was an independent factor $(\beta=-0.072, P=0.002)$ negatively associated with the serum levels of $25(\mathrm{OH}) \mathrm{D}$. As expected, we also demonstrated that serum calcium was an independent factor positively associated with the serum concentrations of $25(\mathrm{OH}) \mathrm{D}(\beta=17.429, P<0.0001)$ in the study. Consequently, to keep adequate serum calcium levels may be an approach to sufficient serum $25(\mathrm{OH}) \mathrm{D}$, by means of increasing the intake of dietary calcium or taking calcium supplements [30].

It was shown that serum apolipoprotein $\mathrm{A} 1 \quad(\beta=2.889, P=0.026)$ was an independent factor positively associated with serum $25(\mathrm{OH})$ $\mathrm{D}$ in very elderly Chinese males, which was similar to the findings by Sun and colleagues [31]. Apolipoprotein A1 is the main structural protein of high density lipoprotein. It can catalyze lecithin cholesterol acyltransferase, transport dermal vitamin $D$ to theliver to be transformed into $25(\mathrm{OH}) \mathrm{D}$ by 25 -hydroxylase [32]. In addition, triglycerides $(\beta=-$ $1.868, P=0.009$ ) was found to be an independent factor negatively associated with serum $25(\mathrm{OH}) \mathrm{D}$ in the present study. Similar inverse associations between serum $25(\mathrm{OH}) \mathrm{D}$ levels and triglycerides were also documented by other studies [33,34]. The potential biological mechanism underlying this relation is still not completely understood but may be mediated, in part, by the effects of dietary calcium [35]. Higher serum 25(OH)D concentrations increase the absorption of intestinal calcium, which may bind to fatty and bile acids and form insoluble lipid-calcium complexes, thereby inhibiting the absorption of cholesterol and increasing fecal excretion [36]. Elevated PTH levels associated with low serum $25(\mathrm{OH}) \mathrm{D}$ concentrations may also account for this association, because higher triglycerides levels has also been observed in states of hyperparathyroidism [37].
Available information on the association between 25(OH)D and alcohol use is controversial. High prevalence of vitamin D deficiency in alcohol-abusing populations were well documented by previous studies $[38,39]$, while some researchers argued that moderate alcohol consumption showed a positive association with plasma levels of 25(OH)D [40, 41]. In line with the findings by Olmos and et al. [29], it was shown in our study that alcohol drinking was an independent factor inversely associated with the serum concentrations of $25(\mathrm{OH}) \mathrm{D}$ $(\beta=-3.126, P=0.031)$. Neupane and et al found that shorter time since last alcohol intake was related to having lower 25(OH)D levels [38]. One possible explanation for alcohol-related vitamin $\mathrm{D}$ deficiency is alcohol can inhibit the enzymatic activity of 25-hydroxylase, therefore impeding the conversion of vitamin D into 25(OH)D [39]. In addition, limiting alcohol consumption has a positive influence on bone mineral density while heavy drinking increases the risk of osteoporotic fractures [42]. As a consequence, elderly males should avoid heavy drinking to reach adequate serum $25(\mathrm{OH}) \mathrm{D}$.

Dermal synthesis is an important source of Vitamin D. Approximately $80 \%$ to $90 \%$ of the vitamin D that an individual requires is produced endogenously following exposure of the skin to ultraviolet Blight (290-320 nm) radiation. Molecularly, under the action of ultraviolet $\mathrm{B}$ radiation, cutaneous 7-dehydrocholesterol is transformed into provitamin $\mathrm{D} 3$ by photolysis reaction, the latter is further converted into vitamin D3 under the effect of thermo isomerization followed by transformation into $25(\mathrm{OH}) \mathrm{D}$ by 25 -hydroxylase in liver [43]. In our current study, sun exposure was found to be an independent factors positively associated with serum $25(\mathrm{OH}) \mathrm{D}(\beta=0.974, P=0.042)$, signifying to have adequate sun exposure is a feasible measure to improve the serum levels of 25(OH)D. Farrar and colleagues examined the efficacy of a dose range of simulated summer sunlight exposures in raising vitamin D status in UK adults of South Asian ethnicity, and found that the $25(\mathrm{OH}) \mathrm{D}$ concentrations rose significantly in all dose groups [44]. A positive effect of sun exposure on $25(\mathrm{OH})$ $\mathrm{D}$ concentrations were also demonstrated by other investigators [43, 45]. It is plausible for elderly males to take sun exposure to attain sufficient serum 25(OH)D.

The limitations of this study should be addressed. First, the crosssectional design of the study prevented us from identifying the causal associations between vitamin D deficiency and the clinical factors investigated. Second, some influential factors such as season and dietary vitamin $\mathrm{D}$ were not taken into consideration in the study. This impeded our fully identifying independent factors for vitamin $\mathrm{D}$ deficiency. Further large-scale studies are warranted that take into consideration as many influential factors as possible.

To draw a conclusion, there is a high prevalence of vitamin $\mathrm{D}$ 
insufficiency and deficiency in very elderly Chinese. Some lifestyle factors are associated with the serum concentrations of $25(\mathrm{OH}) \mathrm{D}$. To have adequate sun exposure, take calcium supplement, and avoid heavy drinking may help to achieve sufficient vitamin $\mathrm{D}$ for very elderly males.

\section{Acknowledgments}

Funding: This work was financially supported by grants from Medical Research Program of Zhejiang Province (reference: 2011KYB014, 2013KYA018 and 2016ZDA002, China), and a grant from Scientific Research Starting Foundation of Zhejiang Provincial People's Hospital (reference: zry2015C002, China).

We would like to greatly acknowledge Baojian Hong and Ming Zhang for their assistances in the assays of BTMs and measurements of bone mineral density, respectively.

\section{References}

1. Holick MF (2007) Vitamin D deficiency. $N$ Engl J Med 357: 266-281. [Crossref]

2. Bruyère O, Slomian J, Beaudart C, Buckinx F, Cavalier E, et al. (2014) Prevalence of vitamin D inadequacy in European women aged over 80 years. Arch Gerontol Geriatr 59: 78-82. [Crossref]

3. Green RJ, Samy G, Miqdady MS, El-Hodhod M, Akinyinka OO, et al. (2015) Vitamin $\mathrm{D}$ deficiency and insufficiency in Africa and the Middle East, despite year-round sunny days. S Afr Med J 105: 603-605. [Crossref]

4. Zhen D, Liu L, Guan C, Zhao N, Tang X (2015) High prevalence of vitamin D deficiency among middle-aged and elderly individuals in northwestern China: its relationship to osteoporosis and lifestyle factors. Bone 71: 1-6. [Crossref]

5. Sadat-Ali M, Al Elq AH, Al-Turki HA, Al-Mulhim FA, Al-Ali AK (2011) Influence of vitamin D levels on bone mineral density and osteoporosis. Ann Saudi Med 31: 602608. [Crossref]

6. Gani LU, How CH (2015) PILL Series. Vitamin D deficiency. Singapore Med J 56: 433-436. [Crossref]

7. El Maghraoui A, Ouzzif Z, Mounach A, Rezqi A, Achemlal L (2012) Hypovitaminosis $\mathrm{D}$ and prevalent asymptomatic vertebral fractures in Moroccan postmenopausal women. BMC Womens Health 12: 11.

8. Anderson JL, May HT, Horne BD, Bair TL, Hall NL, et al. (2010) Intermountain Heart Collaborative (IHC) Study Group. Relation of vitamin D deficiency to cardiovascular risk factors, disease status, and incident events in a general healthcare population. $\mathrm{Am} \mathrm{J}$ Cardiol 106: 963-968. [Crossref]

9. Wang L, Song Y, Manson JE, Pilz S, März W, et al. (2012) Circulating 25-hydroxyvitamin D and risk of cardiovascular disease: a meta-analysis of prospective studies. Circ Cardiovasc Qual Outcomes 5: 819-829. [Crossref]

10. Del Brutto OH, Mera RM, Macias J, Morales G, Zambrano M (2015) Cerebrovascular correlates of vitamin D deficiency in older adults living near the Equator: results from the Atahualpa Project. Int J Stroke 10: 1301-1303. [Crossref]

11. Garland CF, French CB, Baggerly LL, Heaney RP (2011) Vitamin D supplement doses and serum 25-hydroxyvitamin $\mathrm{D}$ in the range associated with cancer prevention. Anticancer Res 31: 607-611. [Crossref]

12. Grineva EN, Karonova T, Micheeva E, Belyaeva O, Nikitina IL (2013) Vitamin D deficiency is a risk factor for obesity and diabetes type 2 in women at late reproductive age. Aging (Albany NY) 5: 575-581. [Crossref]

13. Perna L, Mons U, Kliegel M, Brenner H (2014) Serum 25-hydroxyvitamin D and cognitive decline: a longitudinal study among non-demented older adults. Dement Geriatr Cogn Disord 38: 254-263. [Crossref]

14. Lapid MI, Cha SS, Takahashi PY (2013) Vitamin D and depression in geriatric primary care patients. Clin Interv Aging 8: 509-514. [Crossref]

15. Annweiler C, Schott AM, Rolland Y, Beauchet O (2014) Vitamin D deficiency is associated with orthostatic hypotension in oldest-old women. J Intern Med 276: 285295. [Crossref]

16. Saliba W, Barnett O, Rennert HS, Rennert G (2012) The risk of all-cause mortality is inversely related to serum 25(OH)D levels. J Clin Endocrinol Metab 97: 2792-2798. [Crossref]
17. Schleck ML, Souberbielle JC, Jandrain B, Da Silva S, De Niet S, et al. (2015) A Randomized, Double-Blind, Parallel Study to Evaluate the Dose-Response of Three Different Vitamin D Treatment Schemes on the 25-Hydroxyvitamin D Serum Concentration in Patients with Vitamin D Deficiency. Nutrients 7: 5413-5422. [Crossref]

18. Mackawy AM, Al-Ayed BM, Al-Rashidi BM (2013) Vitamin d deficiency and its association with thyroid disease. Int J Health Sci (Qassim) 7: 267-275. [Crossref]

19. Jones G (2008) Pharmacokinetics of vitamin D toxicity. Am J Clin Nutr 88: 582S-586S. [Crossref]

20. McKibben RA, Zhao D, Lutsey PL, Schneider AL, Guallar E, et al. (2016) Factors Associated with Change in 25-Hydroxyvitamin D Levels Over Longitudinal FollowUp in the ARIC Study. J Clin Endocrinol Metab 101: 33-43. [Crossref]

21. Hill TR, Granic A, Davies K, Collerton J, Martin-Ruiz C, et al. (2016) Serum 25-hydroxyvitamin D concentration and its determinants in the very old: the Newcastle 85+ Study. Osteoporos Int 27: 1199-1208. [Crossref]

22. Jakobsen A, Laurberg P, Vestergaard P, Andersen S (2013) Clinical risk factors for osteoporosis are common among elderly people in Nuuk, Greenland. Int J Circumpolar Health 72: 19596. [Crossref]

23. Li G, Thabane L, Papaioannou A, Adachi JD (2015) Comparison between frailty index of deficit accumulation and fracture risk assessment tool (FRAX) in prediction of risk of fractures. Bone 77: 107-114. [Crossref]

24. Rosen CJ (2011) Clinical practice. Vitamin D insufficiency. N Engl J Med 364: 248 254. [Crossref]

25. Hayes DP (2010) Vitamin D and ageing. Biogerontology 11: 1-16. [Crossref]

26. Ardawi MS, Sibiany AM, Bakhsh TM, Qari MH, Maimani AA (2012) High prevalence of vitamin D deficiency among healthy Saudi Arabian men: relationship to bone mineral density, parathyroid hormone, bone turnover markers, and lifestyle factors Osteoporos Int 23: 675-686. [Crossref]

27. Alkerwi A, Sauvageot N, Gilson G, Stranges S (2015) Prevalence and Correlates of Vitamin D Deficiency and Insufficiency in Luxembourg Adults: Evidence from the Observation of Cardiovascular Risk Factors (ORISCAV-LUX) Study. Nutrients 7: 6780-6796. [Crossref]

28. D'Amour P, Rousseau L, Hornyak S, Yang Z, Cantor T (2011) Influence of secondary hyperparathyroidism induced by low dietary calcium, vitamin $\mathrm{D}$ deficiency, and renal failure on circulating rat PTH molecular forms. Int J Endocrinol 2011: 469783. [Crossref]

29. Olmos JM, Hernández JL, García-Velasco P, Martínez J, Llorca J, et al. (2015) Serum 25-hydroxyvitamin $\mathrm{D}$, parathyroid hormone, calcium intake, and bone mineral density in Spanish adults. Osteoporos Int 2015; [Epub ahead of print].

30. Bonjour JP, Benoit V, Pourchaire O, Rousseau B, Souberbielle JC (2011) Nutritional approach for inhibiting bone resorption in institutionalized elderly women with vitamin D insufficiency and high prevalence of fracture. J Nutr Health Aging 15: 404-409. [Crossref]

31. Sun X, Cao ZB, Tanisawa K, Ito T, Oshima S, et al. (2015) Associations between the Serum 25(OH)D Concentration and Lipid Profiles in Japanese Men. J Atheroscler Thromb 22: 355-362. [Crossref]

32. Cigerli O, Parildar H, Unal AD, Tarcin O, Erdal R, et al. (2013) Vitamin D deficiency is a problem for adult out-patients? A university hospital sample in Istanbul, Turkey. Public Health Nutr 16: 1306-1313. [Crossref]

33. Saedisomeolia A, Taheri E, Djalali M, Moghadam AM, Qorbani M (2014) Association between serum level of vitamin D and lipid profiles in type 2 diabetic patients in Iran. $J$ Diabetes Metab Disord 13: 7. [Crossref]

34. Mendoza V, Villanueva MT, Vargas G, González B, Halabe J, et al. (2013) Vitamin D deficiency among medical residents and its relationship with metabolic indices. Endocr Pract 19: 59-63. [Crossref]

35. Chacko SA, Song Y, Manson JE, Van Horn L, Eaton C, et al. (2011) Serum 25-hydroxyvitamin D concentrations in relation to cardiometabolic risk factors and metabolic syndrome in postmenopausal women. Am J Clin Nutr 94: 209-217. [Crossref]

36. Vaskonen T, Mervaala E, Sumuvuori V, Seppänen-Laakso T, Karppanen H (2002) Effects of calcium and plant sterols on serum lipids in obese Zucker rats on a low-fat diet. BrJ Nutr 87: 239-245. [Crossref]

37. Farahnak P, Lärfars G, Sten-Linder M, Nilsson IL (2011) Mild primary hyperparathyroidism: vitamin $\mathrm{D}$ deficiency and cardiovascular risk markers. $J$ Clin Endocrinol Metab 96: 2112-2118. [Crossref] 
38. Neupane SP, Lien L, Hilberg T, Bramness JG (2013) Vitamin D deficiency in alcoholuse disorders and its relationship to comorbid major depression: a cross-sectional study of inpatients in Nepal. Drug Alcohol Depend 133: 480-485. [Crossref]

39. Naude CE, Carey PD, Laubscher R, Fein G, Senekal M (2012) Vitamin D and calcium status in South African adolescents with alcohol use disorders. Nutrients 4: 1076-1094. [Crossref]

40. Sritara C, Thakkinstian A, Ongphiphadhanakul B, Pornsuriyasak P, Warodomwichit D, et al. (2015) Work- and travel-related physical activity and alcohol consumption: relationship with bone mineral density and calcaneal quantitative ultrasonometry. $J$ Clin Densitom 18: 37-43. [Crossref]

41. van Grootheest G, Milaneschi Y, Lips PT, Heijboer AC, Smit JH, et al. (2014) Determinants of plasma 25-hydroxyvitamin D levels in healthy adults in the Netherlands. Neth J Med 72: 533-540. [Crossref]
42. Maurel DB, Boisseau N, Benhamou CL, Jaffre C (2012) Alcohol and bone: review of dose effects and mechanisms. Osteoporos Int 23: 1-16. [Crossref]

43. Nurbazlin M, Chee WS, Rokiah P, Tan AT, Chew YY, et al. (2013) Effects of sun exposure on $25(\mathrm{OH})$ vitamin D concentration in urban and rural women in Malaysia. Asia Pac J Clin Nutr 22: 391-399. [Crossref]

44. Farrar MD, Webb AR, Kift R, Durkin MT, Allan D, et al. (2013) Efficacy of a dose range of simulated sunlight exposures in raising vitamin D status in South Asian adults: implications for targeted guidance on sun exposure. Am J Clin Nutr 97: 1210-1216. [Crossref]

45. Tran B, Armstrong BK, McGeechan K, Ebeling PR, English DR, et al. (2013) Predicting vitamin D deficiency in older Australian adults. Clin Endocrinol (Oxf) 79: 631-640. [Crossref]

Copyright: (C2017 Bian P. This is an open-access article distributed under the terms of the Creative Commons Attribution License, which permits unrestricted use, distribution, and reproduction in any medium, provided the original author and source are credited. 